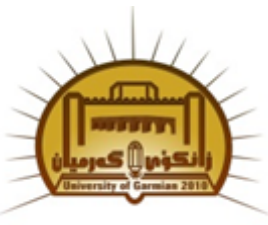

Available online at http://jgu.garmian.edu.krd

Journal of Uni versity of Garmian

JUG

https://doi.org/10.24271/garmian.196355

\title{
Factors Contribute to Speaking Performance Development: Kurdish EFL Summer Course Learners' Perspectives
}

\author{
Hemn Adil Karim ${ }^{1}$, Aso Ali Muhammad ${ }^{2}$ \\ ${ }^{1}$ Department of English, College of Education ,University of Garmian \\ ${ }^{2}$ Ministry of Education
}

Article Info

Received: July, 2019

Revised:August,2019

Accepted:August,2019

\section{Keywords}

Factors, Speaking Performance, EFL, Learners Pers pectives, Teachers

Corresponding Author

Aso_ali50@yahoo.com

\begin{abstract}
Development of English language speaking performance in the EFL classrooms can be shaped by various factors. To explore this, the present study enquired 70 university level Kurdish EFL summer course learners (70 college learners who participated in English language development summer courses). The findings revealed that the learners' perspectives vary. The respondents consider speaking as an important skill and although it is difficult and they don't have enough mastery over. And they are also eager to speak fluently and are willing to participate in various speaking activities. Regardless of having opportunities for improving their speaking, they believe that the time for speaking in conversation classes need to be extended and the use of English language should be more intensive in speaking and non-speaking lectures. Additionally, more than half of the study participants feel satisfied with speaking materials, activities, and facilities. Further, from their point of view, participants are not afraid of teachers' corrections and they are comfortable with talking toteachers. However, their main obstacle is being unable to use English with classmates and teachers in all English sessions. Besides, they feel shy to speak in front of the friends. Therefore, the study suggests that the participants' perspectives to be taken into account to know how to apply all factors to create an atmosphere that aid EFL students in Kurdistan to develop their English speaking performance.
\end{abstract}

\section{Introduction}

\section{An Overview of the Study}

As other second language learners to develop their speaking performance, Kurdish learners with different majors, particularly English, use a lot of ways and try to be competent English speakers. However, sometimes certain problems hinder them developing their English speaking and expressing their ideas in English language classes as a result of lacking of opportunities to practice using English inside and outside the classroom, not having enough exposure to English language, lacking of grammar and vocabulary, being unable to express ideas in a 
right context, not having a correct pronunciation, being in an unmotivated atmosphere where any encouragement cannot be noticed from teachers, classmates, and other people surrounding them, and the differences between their native language and the target language including (grammar, vocabulary, pronunciation, and culture differences). To help students being aware of the problems and knowing the factors assist them develop their speaking performance, the present study tries to explore what previous studies findings and recommendations are and to know EFL Kurdish students' perspectives on the factors that help them enhance their speaking performance and tackle the obstacles they encounter during practicing English.

\section{Statement of the Problem}

To develop their speaking skills ability, many Kurdish EFL learners in Iraqi Kurdistan use various ways and sometimes face some challenges and difficulties in speaking probably because of not having enough grammatical knowledge, extended and varied vocabulary, exposure to the target language, the requirements of academic speaking, and also mainly incorrect pronunciation and the differences between their L1 and the target language (English). Generally most of them spend a large amount of their time to practice and speak English inside and outside classrooms in a proper way but cannot as they do not have enough opportunity to speak in English inside and outside the class, lacking of confidence, and lacking of encouragement from their surroundings (e.g. teachers, classmates, and society). Therefore, they try to develop their speaking performance and express their ideas fluently and accurately, and being comfortable whenever they want to use English. Thus, this study aims at helping Kurdish EFL learners to know what are the major factors contribute to developing their speaking performance by suggesting some useful ways and strategies from students' perspectives to deal with the challenges they face as they speak in English so as to implement the factors assist them develop their speaking abilities.

\section{Research Questions}

This study addresses the following research questions:

What factors make speaking in English classrooms more important skill to be developed among EFL students ?

How can students be facilitated to develop their speaking abilities?

Are learners eager and willing to develop their speaking abilities?

What factors hinder students' development of speaking performance?

\section{Significance of the Study}

Developing speaking performance and expressing ideas in English orally in a correct and proper way have been considered as an important part of knowing the language among EFL learners. In the last few decades a number of studies have explored the factors affecting 
speaking skills or performance development, and hinder its development. Such studies are rare in the field of EFL, especially investigating Kurdish learners' perspectives to know what factors they support more so as to be adopted in teaching English sessions appropriately. Therefore, studies are necessary to closely explore such a topic.

\section{Literature Review}

Speaking as other language skills has a key role in helping language learners to learn a foreign language. This skill is considered as a productive skill than a receptive one, which speaker gives information rather than getting information as in reading and listening. According to Lazaraton (2001) for most people, the ability to speak a language is synonymous with knowing that language since speech is the most basic means of human communication (p. 103). It is a common thought that whenever someone talks about language learners' ability, they say 'competent speakers' or 'native-like speakers', it shows that to able to speak indicates that someone knows the language since there are people who know how to write and read who are not considered as they don't know the language, while people who can speak with having writing and reading problems and they are regarded as they know the language. Ur (1996) focuses on the importance of speaking and states that "of all the four skills [listening, speaking, reading, and writing], speaking seems intuitively the most important: people who know a language are referred to as 'speakers' of that language, as if speaking includes all other kinds of knowing" (120). To McNamara cited in (Koizumi, 2005) speaking can be seen from two perspectives: performance and ability. Performance is defined as "actual instances of language use in real time", which is something that can be observed. On the other hand, ability is an underlying entity that is relatively stable and can be inferred from performance (pp. 2-3).

Furthermore, speaking a language is not an easy task and developing this skill needs efforts and work to be achieved by a language learner. Speaking skills defined by scholars as the ability to communicate and expressing ideas. Kaplan (2002) defines speaking as “it involves understanding the psycholinguistic and interpersonal factors of speech production, the forms, meanings, and processes involved, and how these can be developed" (p. 27). Thornbury (2005) describes the importance of being able to speak a language and interact with people. He believes that it is generally accepted that knowing a language and the ability to speak is not the same. Thus, the statement she knows English doesn't entail the statement she can speak English. This indicates that learning to speak a language is more important than knowing the structure of that language only. Mostly learners of a language are judged through speaking because speaking takes a great part in communication. As Hedge (2002) thinks that speaking is "a skill by which they [people] are judged while first impressions are being formed" (p. 261). Chaney and Burk (1998) considered speaking as "the process of building and sharing 
meaning through the use of verbal or non-verbal symbols in a variety of context" (p. 13). It means that it's a complex process of sending and receiving messages through the verbal (oral) and non-verbal symbols such as gestures and facial expressions. Like other language skills, speaking has a number of sub-skills, which they are very important, especially for language learners. In speaking skills, generally, there are five main sub-skills that they are (pronunciation, grammar, vocabulary, fluency, and accuracy). Through these sub-skills learners can speak academically in a way that can be understood easily.

Perhaps the most difficult aspect of spoken English is that it is almost always accomplished via interaction with at least one other speaker. This means that a variety of demands are in place at once: monitoring and understanding the other speaker(s), thinking about one's own contribution, producing that contribution, monitoring its effect and so on (Lazaraton, 2001, p. 103). This is the main reason that most of the people for the first time use a second language will be shocked as really interacting with an interlocutor. Therefore, for most of the L2 speakers speaking is a difficult and challenging task to deal with and needs a lot of effort or skill to be successful. In addition, Schmitt (2010) claims that "learning speaking whether in first or other language, involves developing subtle and detailed knowledge about why, how, and when to communicate" (p. 196).

The ways to promote oral skills in the ESL/EFL classroom are suggested as major speaking activities by Lazaraton (2001) to be implemented in speaking: discussions, speeches, role plays, conversations, audio-taped oral dialogue journals, and other accuracy-based activities (p. 106). Kayi (2006) also recommended some activities to promote speaking in L2 including 'discussions, role play, simulations, information gap, brainstorming, storytelling, interviews, story completion, reporting, playing cards, picture narrating, picture describing, and finding the differences'. In addition, Chastain (1988) claims that "speaking a language involves more than simply knowing the linguistic components of the message, and developing language skills requires more than grammatical comprehension and vocabulary memorization" (p. 270). He suggests that real opportunity that teachers can provide students with is the use of language as a "medium of communication" in everyday classes. In other words, classroom should be a place in which students express their ideas and participate in class activities to develop their speaking. Thornbury (2005) also puts emphasis on the importance of practice in developing speaking skills performance as he states that "shortage of opportunities for practice is identified as an important contributing factor to speaking failure. And by practice is meant, not practice of grammar and vocabulary, but practice of interactive speaking itself" (p. 28). He also states that "fundamental to the view that speaking is a cognitive skill is the idea that knowledge becomes increasingly automated through 
successive practice. Practice makes - if not perfect - at least, fluent".

Classroom interaction has also been seen as an important factor that language learners can develop their speaking performance with; for instance, Chastain (1988) shows the importance of interaction between students inside classrooms, and its effects on students' speaking development in some ways: firstly, interaction with colleagues helps to "convert thoughts to speech", "give students opportunities to become better acquainted and to feel more comfortable with each other", and "keeps them involved in the class and gives them the impression that their participation is important" (p. 271).

A number of studies have been conducted to find out the factors affecting speaking performance development. Khadidja (2010) conducted a study using questionnaire to both students and teachers of oral expression to examine the impact of classroom interaction on the learners' speaking skill development. The findings reveled that both learner and teacher participants consider classroom interaction as an important pedagogical strategy in enhancing speaking skill. According to another research by Mart (2012, p. 91) speaking skills can be developed through reading as there is a strong relationship between both skills. The research concludes that extensive reading improves communication skills and helps to improve the ability to express ideas, meanwhile enriching vocabulary items that influence speaking fluency. He further claims that through reading learners can be introduced to a broader body of language and context and they can improve their grammar, which all help developing more sophisticated speaking skills. Vilimec (2006) also conducted a study on developing speaking skills; found that students together with teachers are the most important ones who influence the process of speaking. The aim of the study is how the position of the teacher can influence the process of speaking skills. From Vilimec's point of view, teachers' organization of activities, preparing and considering different aspects related to the organization is one of the crucial phases. Florez (1999) also in a paper about improving adult English language learners' speaking skills claims that "by considering what good speakers do, what speaking tasks can be used in class, and what specific needs learners report, teachers can help learners improve their speaking and overall oral proficiency" (p. 4). Moreover, according to Bashir, Azeem \& Dogar (2011) who did a research about the factors affecting students' English speaking skills claim that "speaking doesn't mean merely uttering words through mouth, it means conveying the message through the words of mouth" (p. 35). They further suggest that to develop students' English speaking, teachers can follow the same natural way of learning to speak the mother tongue, which is just by listening and repeating.

Concerning the effects of vocabulary knowledge and lexis on speaking performance development, some studies have been done. For example, Koizumi (2005) in a study examines relationships 
between productive vocabulary knowledge in terms of size and depth, and speaking performance including (fluency, accuracy, syntactic complexity, and lexical complexity) of Japanese learners of English at the novice level. The results show that speaking performance is mainly related to productive vocabulary knowledge. In addition, Sakale and Seffar (2012) conducted a study to discover the role of lexis in Moroccan EFL learners' speaking production. The participants were EFL teachers and high school students who were surveyed to know their perceptions of the speaking skill and the corresponding high significance of lexis in this instance. The results showed that according to the participants' viewpoint vocabulary deficiency is the main factor behind students' inability to speak English. Oya, Manalo, and Greenwood (2009) also examined the impact of language and vocabulary knowledge on speaking performance of English language Japanese learners in New Zealand. The findings showed that vocabulary knowledge correlated with fluency, accuracy, complexity, and global impression aspects of speaking performance, and also language contact including (studying English, staying in Englishspeaking countries, speaking English outside of school and with non-native speakers, and reading) correlate positively with various aspects of speaking performance. Whereas, watching television negative correlates with speaking accuracy.

Some other studies have also been conducted to see the effectiveness of some other factors on speaking performance. Efrizal (2012, p. 133) conducted a study to investigate whether using Communicative Language Teaching (CLT) method improves first year Indonesian students' English speaking. Based on the research results there are improvements in students' speaking achievement through using CLT method. A team of teachers (Romero, Bernal, \& Olivares, 2012) conducted a research to see whether using songs encourages students and gives them opportunity to develop their English speaking skills. They found that learners were able to acquire new words and pronouncing them freely and accurately in a non-threatening environment. They were also motivated to learn English. Furthermore, a research has been done by Chotirat \& Singwongsuwat (2011) to examine the effects of scripted and non-scripted role play activities on Thai EFL college students' oral performance by attending to the repair organization. The findings showed that although the types of repair organization in both role play activities are the same and improve students' oral ability, non-scripted ones provide students with better opportunity to practice relevant language use features in naturally occurring conversation. Rahimy and Safarpour (2012) also studied the effects of using role-play as a classroom activity on Iranian EFL learners' speaking ability. They concluded that using role-play as classroom activities enhanced speaking performance of Iranian EFL learners as role-playing provides learners with enjoyable and interesting 
environment, which leads them to participate actively.

Moreover, in a case study, Afrilyasanti and Basthomi (2011) investigate the implementation of digital storytelling in teaching speaking Indonesian EFL students, found that using digital storytelling helps students produce communicative and understandable story, understand other friends' story, and participate actively in speaking class activities. Figueiredo and Mota (2009) in their study seek the effects of exposing learners to an instructional treatment in which speaking is approached as a skill with specific characteristics - that is, in its own right, on EFL learners in oral performance. The findings revealed that there was trend toward gains in oral fluency after the treatment. In addition, Zhang (2009) in his paper puts emphasis on the importance of pronunciation for learners and the factors affecting native-like pronunciation. The paper also categorized the affecting factors into internal and external factors. Internal factors focuses on L2 learners themselves that relates to biological factors and individual differences, while the external ones involve L2 learners' learning environment, native language, exposure, and educational factors. Griffiths (2004) also conducted a study to explore the strategies used by international students for language skills development to their studies in English. The study results reveal the importance of reading in developing both receptive (reading and listening) and productive (writing and speaking) skills, and also the effectiveness of interactive classroom exercises.

Students' unwillingness to speak English in language classroom is also another issue that makes Riasati (2012) to conduct a study exploring Iranian EFL learners' perceptions of factors that influence their willingness to speak in language classrooms. He found that the factors mostly contribute to willingness to speak are task type, topic of discussion, interlocutor, teacher, class atmosphere, personality, and self-perceived speaking ability. In addition, Nazara (2011) investigates students' perceptions on developing EFL speaking skills, found that participants believed that speaking is important and their speaking mastery is high. The findings also showed that the participants have willingness to develop their speaking as they got enough opportunities to improve their speaking in speaking classes. Although they got proper opportunity to improve speaking, they responded that the time provided for practicing speaking in speaking classes is too limited, that is why they suggested that they should be provided with more time to practice their speaking in speaking classes as there are a big number of students in each classroom.

Moreover, speaking difficulties and problems among EFL/ESL students have been studied for decades. A group of researchers (Tanveer, 2007; Zhengdong, 2012; Juhana, 2012; Akasha, 2013; and Ariyanti, 2016) studied the factors that considered causing speaking difficulties and problems, and negatively affect communicating 
in the target language including (feelings of anxiety and the factors it can possibly stem from within both the classroom environment and out of classroom in the wider context, apprehension, nervousness, lack of time, language support, and knowledge) and also psychological barriers such as (fear of making mistake especially fear of being laughed at by their friends, shyness, anxiety, lack of confidence, and lack of motivation). Furthermore, the problems with oral skills development of ESL students like insufficient opportunities to speak English in lectures and tutorials, lack of a focus on language improvement in the curriculum, and the inputpoor environment for spoken communication in English outside class).

Based on the explanations above the researchers have found, speaking performance can be developed through some factors including teaching and learning methods and strategies, classroom activities, classroom participation and interaction, students' willingness to develop, and having ample opportunity to use the target language inside or outside classes. On the contrary, the lack of the above factors can hinder speaking performance development.

\section{Methodology}

\subsection{Participants and Setting}

The participants in this study are 70 Kurdish native speaker learners from different university level specializations including (English, Computer Science, Information Technology, General Science, Kindergarten, Mathematics,
Nursing, Medicine, Law, Social Sciences, Agriculture, and Business Administration), who are taking English language development summer course in Kalar Twon, Sulaimani Governarate. The subjects were aged between 1838 and their experience of learning English was between 2-17 years. The questionnaire was distributed to almost all the centers where English language development course taken place. Some of the centers refused to allow the researchers to do the survey. Meanwhile, some students in the other courses were not ready to answer the questionnaire items.

\subsection{Instruments and Procedures}

The study instrument is an adapted version of the (Nazara's 2011) questionnaire about students' perceptions on EFL speaking development, which includes eighteen items grouped into five main categories. They are distributed among the student participants, which consists of two parts. The first part is to know the participants' background information including (age, gender, stage, specialization, and years of learning English), while the second part includes some questions about their perspectives towards the factors help them enhance their speaking performance, their beliefs on speaking mastery level, their eagerness to improve their oral abilities, opportunities and time given for practicing speaking, speaking materials and activities provided, and classroom atmosphere and psychological barriers hinder developing speaking performance. 
Students answered the questions inside the classroom as the researchers were explaining the items. After collecting all the papers, the answers are analyzed qualitatively.

Furthermore, the data analysis is based on the participants' responses in the questionnaire that qualitatively analyzes their perspectives towards the factors contribute to enhance their speaking performance. In addition, the results of the study are discussed, then pedagogical implantations, limitations of the study, suggestions for further researches, and conclusions are presented.

\section{Data Analysis and Discussion of Findings}

In order to know the results and how the respondents reply to the five main categories and the related items that reveals their attitudes towards the factors enhance their English language speaking performance, the following sections are given as the analysis of collected data and discussion of the findings.

Table 1: Students' Belief in their Speaking Mastery Level

\begin{tabular}{|c|c|c|c|c|}
\hline$\dot{4}$ & $\begin{array}{c}\text { Stu dents' Belief in their } \\
\text { Speaking Mastery } \\
\text { Level }\end{array}$ & & & \\
\hline$\dot{z}$ & 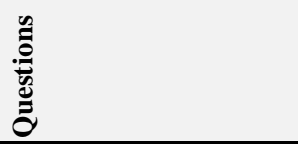 & 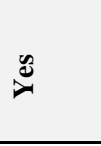 & z & 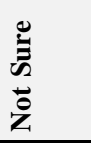 \\
\hline 1 & $\begin{array}{l}\text { Is your speaking mastery } \\
\text { high? }\end{array}$ & $14.28 \%$ & $52.85 \%$ & $32.85 \%$ \\
\hline 2 & $\begin{array}{l}\text { Is speaking difficult to } \\
\text { you? }\end{array}$ & $47.14 \%$ & $42.85 \%$ & $10 \%$ \\
\hline 3 & $\begin{array}{l}\text { Is speaking important to } \\
\text { you? }\end{array}$ & $100 \%$ & $00 \%$ & $00 \%$ \\
\hline
\end{tabular}

According to the first item in Category A (Is your speaking mastery high?) $14.28 \%$ of the participants replied with (yes). Whereas, $52.85 \%$ with (no) and $32.85 \%$ with (not sure). For the second item (Is speaking difficult to you?), the subjects answered as follow; $47.14 \%$ (yes), $42.85 \%$ (no), and $10 \%$ are in nutral position. Surprisingly and expectedly, all the respondents answered with (yes) for the third item (Is speaking important to you?), while the two other options (no and not sure) left blank.

According to the results shown in the analysis of the participants' reponses to Students' Belief in their Speaking Mastery Level, it could be concluded that most of the subjects don't have control over their speaking, and approximately half of them think speaking is difficult, and imprssively all of them believe that speaking is a pivotal skill to have mastery in. Thus it shows that the programs and classrooms in EFL classes everywhere in the country should be tailored to meet the learners' needs in speaking classes.

Table 2: Respondents' Eagerness to Develop Speaking Skill

\begin{tabular}{|c|c|c|c|c|}
\hline 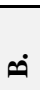 & $\begin{array}{l}\text { Respondents' Eagerness to } \\
\text { De velop Speaking Skill }\end{array}$ & & & \\
\hline$\dot{z}$ & 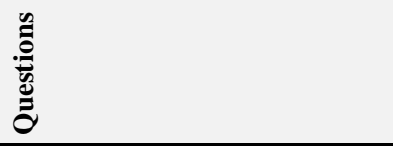 & $\stackrel{\theta}{\approx}$ & z & 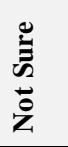 \\
\hline 1 & $\begin{array}{l}\text { Are you eager to speak English well } \\
\text { and fluently? }\end{array}$ & $98.57 \%$ & $1.42 \%$ & $00 \%$ \\
\hline 2 & $\begin{array}{l}\text { Are you willing to participate in } \\
\text { seminars, speech contests, debates, } \\
\text { and other programs requiring speaking } \\
\text { skills? }\end{array}$ & $88.57 \%$ & $5.71 \%$ & $5.71 \%$ \\
\hline
\end{tabular}


In Category $\mathrm{B}$, for the first item which asks participants whether they are eager to speak English well and fluently, nearly all $98.57 \%$ relpied with (yes). On the other hand, 1.42\% chose (no), and none answered with (not sure). Similar to the first item, $88.57 \%$ answered with (yes) the second item (Are you willing to participate in seminars, speech contests, debates, and other programs requiring speaking skills?). Whereas, both (no and not sure) received the same rate $5.71 \%$ each.

Depending on the results shown in the analysis of Table 2, respondents' responses reveal that eagerness to speaking performance development is considerably high. Besides, willingness to participate in daily activities especially in seminars, debates, speech contests, conversations, discussions, etc. is significant and essential. Therefore, EFL learners' eagerness to speak in English and willingness to be engaged in class activities in English leads teachers to provide them with ample opportunities to practice speaking and enhance their performance appropriately.

Table 3: Opportunity and Time for Practicing Speaking

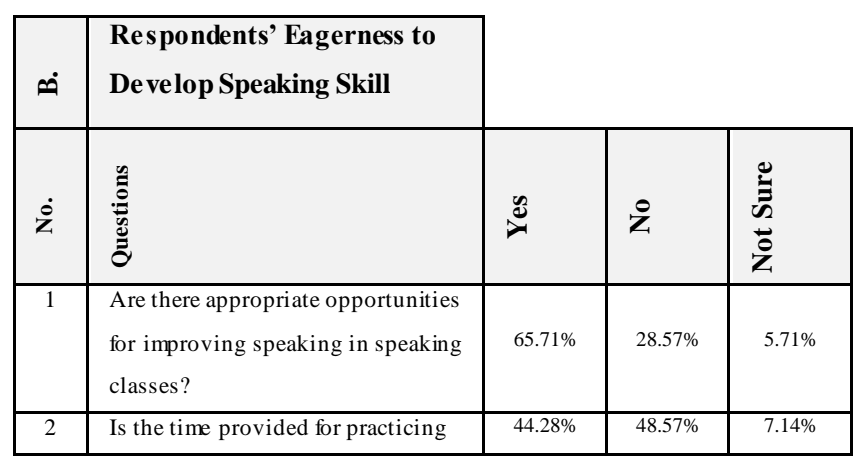

\begin{tabular}{|c|l|l|l|l|}
\hline & $\begin{array}{l}\text { speaking in speaking classes too } \\
\text { limited? }\end{array}$ & & \\
\hline 3 & $\begin{array}{l}\text { Should the time provided for } \\
\text { practicing speaking in speaking } \\
\text { classes be lengthened? }\end{array}$ & $92.85 \%$ & $5.71 \%$ & $1.42 \%$ \\
\hline 4 & $\begin{array}{l}\text { Is proper opportunity to develop } \\
\text { speaking skills provided by teachers } \\
\text { in non-speaking classes? }\end{array}$ & $54.28 \%$ & $37.14 \%$ & $8.57 \%$ \\
\hline 5 & $\begin{array}{l}\text { Is it necessary to have more } \\
\text { intensive use of English in non- } \\
\text { speaking classes? }\end{array}$ & $65.71 \%$ & $22.85 \%$ & $11.42 \%$ \\
\hline
\end{tabular}

Category $\mathrm{C}$, which concentrates on the questions to know the extent of opportunity and the amount of time given for practicining speaking skills, consists of five items. Item number one that asks whether there are appropriate opportunies for speaking improvement in speaking sessions, $65.71 \%$ answered (yes), while $28.57 \%$ chose (no) and $5.71 \%$ are not sure. Their response to the second item which inquires (whether the time provided for practicing speaking in speaking classes are limited) almost equal in between (yes 44.28\%) and (no 48.57\%), while 7.14 were (not sure). Item number three presents information which clarifies that $92.85 \%$ which is almost all of the respondents replied with (yes) when questioned whether the time provided for practicing speaking in speaking classes be lengthened. While $5.71 \%$ responded with (no). Whereas, $1.42 \%$ of them are uncertain about the item. Participants' answers for the fourth item tell that $54.28 \%$ goes with (yes) when confronted with the question "Is proper opportunity to develop speaking skills provided by teachers in nonspeaking classes?". Simultaneously, 37.14\% 
of them had (no), while $8.57 \%$ have doubt to take sides. The last item in Category $\mathrm{C}$, which is about the necessity of having more intensive use of English in non-speaking classes, two-third of the respondents $-65.71 \%$ - support the idea. In contrast, $22.85 \%$ disagree with it, and exactly half of this number are in neutral position which is $11.42 \%$.

In brief, the respondents' answers show that the first option (yes) outwheighed the other two options. Thus it shows that they support the idea of providing more opportunity and lengthening time to practice and improve their speaking performance in speaking and non-speaking sessions. The participants are also interested in using English intensively in the English lectures.

Table 4: Speaking Materials, Activities, and Facilities

\begin{tabular}{|c|l|l|l|l|}
\hline & $\begin{array}{l}\text { Respondents' Eagerness to } \\
\text { De velop Speaking Skill }\end{array}$ & \multicolumn{2}{|l|}{} \\
\hline & $\begin{array}{l}\text { Dex } \\
\text { exciting for developing speaking } \\
\text { skills? }\end{array}$ & $58.57 \%$ & $35.71 \%$ & $5.71 \%$ \\
\hline 2 & $\begin{array}{l}\text { Do the activities in speaking classes } \\
\text { empower students to speak English? }\end{array}$ & $65.71 \%$ & $17.14 \%$ & $17.14 \%$ \\
\hline 2 & $\begin{array}{l}\text { Are the learning facilities in speaking } \\
\text { classes appropriate for interaction in } \\
\text { English? }\end{array}$ & $54.28 \%$ & $35.71 \%$ & $10 \%$ \\
\hline
\end{tabular}

Category D, which puts emphasis on how the speaking materials, activities, and facilities are related to developing students' speaking abilities, empowering students to speak with the tearget language and interaction level in English classes. The answers to item number one in this category reveals that more than half of the subjects $(58.57 \%)$ show their approval of materials in speaking sessions as exciting to boost their speaking. While, $35.71 \%$ disapprove it, meanwhile a small number show uncertainty in their responses. For the second item that asks if the speaking classes empower students to speak English, $65.71 \%$ preferred (yes), while coincidently (no and not sure) options received the same average $17.14 \%$. This result shows that one third of the respondents either disagree with or unsure of the item. The last item in this category, which concentrates on the facilities provided in speaking lectures and their effect on the extent to which interactions occur, got $54.28 \%$ (yes) from the participants. Whereas, $35.71 \%$ answered with (no), and $10 \%$ are uncertain about the issue.

All in all, depending on the answers to the items in Category D, despite their approval, approximately half of the students are not satisfied with the provided activities, materials, and facilities in English speaking classes, which convey a message that teachers have to make a good effort to meet the needs 
of learners in enhancing their speaking performance in class meeting sessions.

Table 5: Classroom Climate and Students'

Psychological Barriers

\begin{tabular}{|c|l|l|l|l|}
\hline \multirow{2}{*}{\begin{tabular}{|c|l|l|} 
Respondents' Eagerness to \\
De velop Speaking Skill
\end{tabular}} & \multicolumn{2}{|l}{} \\
\hline 1 & $\begin{array}{l}\text { Do you always use English in all } \\
\text { interactions with class mates in all } \\
\text { sessions? }\end{array}$ & $14.28 \%$ & $67.14 \%$ & $18.57 \%$ \\
\hline 2 & $\begin{array}{l}\text { Do you always communicate in } \\
\text { English with teachers in all } \\
\text { speaking and non-speaking classes? }\end{array}$ & $18.57 \%$ & $75.71 \%$ & $5.71 \%$ \\
\hline 3 & $\begin{array}{l}\text { Do you feel shy to speak English } \\
\text { due to laughing of classmates? }\end{array}$ & $54.28 \%$ & $37.14 \%$ & $8.57 \%$ \\
\hline 4 & $\begin{array}{l}\text { Do teachers scold (angrily criticize) } \\
\text { when you speak incorrectly? }\end{array}$ & $20 \%$ & $75.71 \%$ & $4.28 \%$ \\
\hline 5 & $\begin{array}{l}\text { Don't you speak because of feeling } \\
\text { afraid of teachers? }\end{array}$ & $14.28 \%$ & $65.71 \%$ & $20 \%$ \\
\hline
\end{tabular}

Category $\mathrm{E}$ as the last category investigates the effects of factors such as classroom climate and students' psychological barriers. It consists of five items that shed light on in detail in the analysis below. Being asked whether using English in all interactions with peers during the classroom meetings, $14.28 \%$ replied with (yes) and $18.57 \%$ with (not sure), while two-thirds of the subjects $(67.14 \%)$ answred with (no), which clarifies that students are in need to be assisted using English with classmates.

Based on the respondents' answers for the second item, which are $18.57 \%$ (yes), $75.71 \%$ (no), and $5.71 \%$ (not sure), a large number of them refuse to rely on English language as they speak with teachers in all
English sessions no matter there will be speaking or non-speaking sessions.

More than half of the subjects $(54.28 \%)$ think that they feel shy to speak in English because their classmates laughing at them, and $8.57 \%$ are not sure. While $37.14 \%$ do not think friends laughing prohibit them from talking in English inside the lectures. In addition, as participants were asked whether teachers scold them when they make a mistake while expressing their ideas in English and participating in class activities. Most of them (75.71\%) believe that teachers do not criticize them harshly. However, $4.28 \%$ are in neutral position, and $20 \%$ think that teachers correction is a psychological barrier to develop their speaking.

Concerning the last item in the present category, $14.28 \%$ feeling afraid of teachers is a barrier to speaking English. Meanwhile, 20\% are unsure about the matter, whereas two-thirds of them (65.71) think the cause of being passive in speaking classes is not due to the feeling afraid of teachers.

In general, responses to the last domain of the questionnaire uncover that in order to involve Kurdish EFL students to interact and communicate actively in English classes, teachers have to create an atmosphere accordingly. In addition, helping out students is necessary to tackle the psychological barriers such as feeling shy of the classmates or being afraid of teachers' criticism. Consequently, 
students can take advantage of such a factor to develop their speaking performance.

\section{Conclusions}

The findings of the research conclude that there are a number of factors which enhance their speaking performance. To begin with, summer course participants, who responded to the questioonaire items, are not capable enough to master their speaking since they claim that speaking is a difficult skill to be controlled. In spite of these facts, they consider speaking as a vital skill to know as an English learner in English-medium classes. In addition, the sample's answers show that becoming eager to improve speaking abilities can be clearly noticed and they are also willing to be the center of the class and autonomously learn through daily participation.

The findings reveal that speaking classes will almost be an appropriate factor for improving speaking if an appropriate amount of time to be provided for speaking and to be lengthened when necessary. Besides, if proper opportunity to be provided in the other lectures except speaking ones. And it is also necessary to have students use English language more intensively in non-speaking classes instead of using their first language.

The results also uncover that, materials, activities, and facilities used in speaking classes are exciting and give learners more control over speaking and facilitates them to interact in the target language. However, there are responses that deny the excitement of speaking materials and activities to let students develop their speaking in communicative class activities.

Communicating with colleagues and instructors using english inside lectures and also feeling shy because of feeling embarrassed of being laughed by classmates are the major negative factors impact on the students' oral abilities. On the other hand, most of resposes clarify that teachers are helpful and the source of certainty, as they do not angrily criticize students when they make mistakes speaking in English.

\section{References}

1. Afrilyasanti, R. \& Basthomi, Y. (2011). Digital Storytelling: A Case Study on the Teaching of Speaking to Indonesian EFL Students. Language in India, 11, 81-91.

2. Akasha, O. (2013). Exploring the Challenges Facing Arabic-Speaking ESL Students \& Teachers in Middle School. Journal of ELT and Applied Linguistics, 1 (1), 12-31.

3. Ariyanti, M. (2016). Psychological Factors Affecting EFL Students' Speaking Performance. Asian TEFL, 1 (1), 77-88.

4. Basher, M., Azeem, M. \& Dogar, A. H. (2011). Factor Effecting Students' English Speaking Skills. British Journal of Arts and Social Science, 2(1), 34-50.

5. Chaney, A. L. \& Burk, T. L. (1998). Teaching Oral Communication in Grades $K-8$. Boston: Allyn \& Bacon.

6. Chastain, K. (1988). Developing SecondLanguage Skills: Theory and Practice ( ${ }^{\mathrm{rd}} \mathrm{Ed}$.). New York: Harcourt Brace Jovanovich. 
7. Chotirat, S. \& Sinwongsuwat, K. (2011). Effects of Scripted and Non-scripted Role Play Activities on Oral Performance: A Case Study of Repair Organization in Conversation of Thai College Students. Paper presented in the $3^{\text {rd }}$ International Conference on Humanities and Social Sciences, Prince of Songkla University.

8. Efrizal, D. (2012). Improving Students' Speaking through Communicative Language Teaching Method at Mts Ja-alhaq, Sentot Ali Basa Islamic Boarding School of Bengkulu, Indonesia. International Journal of Humanities and Social Sciences, 2(20), 127-134.

9. Figueiredo, E. H. Diniz de \& Mota, M. B. (2009). L2 Speech Production in the Classroom: The Effects of Treating Speaking in its Own Right. Revista Intercambio, XIX, 101-124.

10. Florez, M. A. C. (1999). Improving Adult English Language Learners' Speaking Skills. National Center for ESL Literacy Education, 1-4.

11. Griffiths, C. (2004). Studying in English: Language Skills Development. Occasional Paper No. 5, AIS St Helens, Auckland, New Zealand.

12. Hedge, T. (2000). Teaching and Learning in the Language Classroom. Oxford: Oxford University Press.

13. Juhana, J. (2012). Psychological Factors that Hinder Students from Speaking in English Class: A Case Study in a Senior High School in South Tangerang, Banten, Indonesia. Journal of Education and Practice, 3 (12), 100-110.

14. Kaplan, R. B. (Ed.). (2000). The Oxford Handbook of Applied Linguistics. New York: Oxford University Press.

15. Kayi, H. (2006). Teaching Speaking: Activities to promote Speaking in a Second Language. The Internet TESL Journal, XII(11). Retrieved June
21, 2014, from http://iteslj.org/Articles/KayiTeachingSpeaking.html

16. Khadidja, K. (2010). The Effect of Classroom Interaction on Developing the Learner's Speaking Skill: The Case of Third Year LMD Students of English at Constantine University. Master's thesis, Mentouri University - Constantine Algeria.

17. Koizumi, R. (2005). Relationships between Productive Vocabulary Knowledge and Speaking Performance of Japanese Learners of English at the Novice Level. Doctoral dissertation. University of Tsukuba, Tsukuba, Japan.

18. Lazaraton, A. (2001). Teaching Oral Skills. In M. Celce-Murcia (Ed.) Teaching English as a Second or Foreign Language (pp. 103-115). Boston: Heinle and Heinle.

19. Mart, C. T. (2012). Developing Speaking Skills through Reading. International Journal of English Linguistics, 2 (6), 91-96.

20. Nazara, S. (2011). Students' Perception on EFL Speaking Skill Development. Journal of English Teaching,1 (1), 28-43.

21. Oya, T., Manalo, E. \& Greenwood, J. (2009). The Influence of Language Content and Vocabulary Knowledge on the Speaking Performance of Japanese Students of English. The Open Applied Linguistics Journal, 2, 11-21.

22. Rahimy, R. \& Safarpour, S. (2012). The Effect of Using Role-Play on Iranian EFL Learners' Speaking Ability. Asian Journal of Social Sciences and Humanities, 1(3), 50-59.

23. Riasati, M. J. (2012). EFL Learners' Perception of Factors Influencing Willingness to Speak 
English in Language Classrooms: A Qualitative Study. World Applied Sciences Journal, 17(10), 1287-1297.

24. Romero, M. D., Bernal, L. T. \& Olivares, M. C. (2012). Using Songs to Encourage Sixth Graders to Develop English Speaking Skills. PROFILE, 14(1), 11-28.

25. Sakale, S. \& Seffar, S. (2012). The Role of Lexis in Developing EFL Learners' Speaking Skill. Sino-US English Teaching, 9(9), 1524-1531.

26. Schmitt, N. (2010). An Introduction to Applied Linguistics. New York: Oxford University Press.

27. Tanveer, Muhammad (2007, August). Investigation of the Factors that Cause Language Anxiety for ESL/EFL Learners in Learning Speaking Skills and the Influence it Casts on Communication in the Target Language. Master's thesis, University of Glasgow.
28. Thornbury, S. (2005). How to Teach Speaking. New York: Longman.

29. Ur, P. (1996). A Course in Language Teaching: Practice and Theory. Cambridge: Cambridge University Press.

30. Vilimec, E. (2006). Developing Speaking Skills. MA thesis, University of Pardubice, Czeck Republic.

31. Zhang, Q. (2009). Affecting Factors of NativeLike Pronunciation: From a Comprehensive Perspective. (27) 2. 33-52.

32. Zhengdong, G. (2012). Understanding L2 Speaking Problems: Implications for ESL Curriculum Development in a Teacher Training Institution in Hong Kong. Astralian Journal of Teacher Education, 37 (1), 43-59. 